\title{
Socioeconomic variation in survival from childhood leukaemia in northern England, 1968-2010
}

\author{
K Njoku ${ }^{1}$, N Basta ${ }^{1}$, K D Mann ${ }^{1}$, R J O McNally ${ }^{1}$ and M S Pearce ${ }^{\star, 1}$ \\ ${ }^{1}$ Institute of Health \& Society, Newcastle University, Sir James Spence Institute, Royal Victoria Infirmary, \\ Newcastle upon Tyne NE1 4LP, UK
}

Background: Despite marked improvements in childhood leukaemia survival, 20\% still die within 5 years of diagnosis. The aim of this study was to evaluate the relationship between socioeconomic status, as assessed by paternal occupation at birth, and survival from childhood leukaemia in children, using data from the Northern Region Young Persons Malignant Disease Registry.

Methods: All 1007 cases of leukaemia in children aged 0-14 years, diagnosed between 1968 and 2010 and registered with the Registry were studied. Paternal occupational social class at the time of the child's birth was obtained and analysed in relation to survival using Cox-proportional regression.

Results: Compared with the most advantaged group (I/II), those in the middle group (IIIN/M) had a 68\% increased risk of death, while those in the least advantaged group (IV/N) had $86 \%$ higher risk for acute lymphoblastic leukaemia. While the survival advantage of children in class I/II was apparent from the time of diagnosis, survival for children in groups IIIN/M and IV/V were comparable until 3-4 years after diagnosis, when they began to minimally diverge.

Conclusion: The existence of such socioeconomic disparities cannot be attributed to accessibility to health care in the United Kingdom. Further research into the likely factors underlying these disparities is required.

Advances in diagnostic and treatment modalities over time as well as risk stratified patient management have led to marked improvement in survival from childhood leukaemia (Cancer Research UK, 2012). However, not all children benefit from these advances as $20 \%$ still die within 5 years of diagnosis (Lightfoot et al, 2012). As such, it is important to identify patient sub-groups with differences in outcomes to focus efforts and further improve survival rates.

Socioeconomic status is one of the strongest and most consistent predictors of health (Adler and Newman, 2002). Socioeconomic disparities in several health indices, such as life expectancy and mortality continue to be present in the developed world (Marmot et al, 2008). Socioeconomic disparities in cancer survival have been described for many adult malignancies, with more advantaged patients having better survival than deprived patients (Chang et al, 2012; Simard et al, 2012; Quaglia et al, 2013; Saldana-Ruiz et al, 2013), including studies that have shown such disparities for most adult cancers in England (Coleman et al, 2004; Rachet et al, 2010). However, fewer studies have examined the influence of socioeconomic factors on survival from childhood cancers, especially leukaemia. Those that have point to modest disparities in leukaemia survival in childhood at most (McWhirter et al, 1983; Coebergh et al, 1996; Schillinger et al, 1999; Charalampopoulou et al, 2004; Ribeiro et al, 2007; Tang et al, 2008; Kent et al, 2009; Basta et al, 2011; Son et al, 2011; Lightfoot et al, 2012). Most studies have depended on areal measures of community deprivation without any individual assessment of socioeconomic status (Basta et al, 2011). This leaves findings open to questions regarding the ecological fallacy, whereby the use of aggregated data can lead to incorrect assignment of individual explanatory variables (in this case, the difference between individual level social class, as opposed to aggregated measures that come from using areal census data). 
In many of the investigations, clinical and other prognostic features of the disease have not been accounted for, thus raising the possibility that factors predictive of the characteristics of leukaemia incidence and status at diagnosis, such as white blood cell count (Smith and Hann, 2004) may confound or explain some of the prognostic effects of social class. Age at diagnosis, sex, calendar period of diagnosis, and other important determinants of leukaemia survival should also be taken into consideration when assessing the effect of social class on childhood leukaemia survival (Pui et al, 2011).

Establishing the existence of and determining the reasons for childhood cancer inequalities remains high on both the research and policy agenda of the United Kingdom and of most developed nations of the world (Rachet et al, 2010). This study examined whether survival from childhood leukaemia varied with socioeconomic status, assessed by paternal occupation at birth, in northern England. Further, it assessed whether interactions exist between socioeconomic status and prognostic factors on survival.

\section{MATERIALS AND METHODS}

The study population included all cases of leukaemia in children aged 0-14 years, diagnosed during the period of 1968-2010 and registered with the Northern Region Young Persons Malignant Disease Registry (NRYPMDR). Of the over 6000 registry cases, 1007 are childhood leukaemia cases. The NRYPMDR was established in 1968 and covers the Northern Region of England as defined in 1972, excluding the district of Barrow-in-Furness in Cumbria. The registry is located within the Newcastle upon Tyne Hospitals NHS Foundation Trust, which is the regional specialist centre for cancer in children and adolescents. Cases in the 0- to 14year age group have been collected prospectively since 1968, while those in the 15- to 24-year age group were identified retrospectively for the period 1968 to 1985 and have been collected prospectively since 1985. Registration with NRYPMDR is not mandatory, but cases are identified from multiple sources: consultants throughout the region notify the registry of any malignancies in children and young adults, and death certificates and hospital admissions are regularly scrutinised. Data are periodically cross-checked with regional and national cancer registries to ensure information is as accurate and complete as possible. Overall ascertainment of cancers is believed to be at least $98 \%$ complete (Cotterill et al, 2000). Responsible clinicians and general practitioners are contacted at regular intervals ( $\sim 6$ monthly) to determine patients' current vital status. The study region is a mixture of several heavily populated urban areas and widespread rural communities. It has a predominantly Caucasian population of 3.1 million (ethnic minorities account for under $2 \%$ ) with $\sim 37000$ live births per year. There is relatively little migration in and out of the region compared with other areas of the United Kingdom.

A copy of the birth certificate, a public document in the United Kingdom, is obtained by the registry whenever possible. Paternal occupation, as routinely recorded on birth certificates, was coded according to the 1990 Standard Occupational Classification. The paternal occupational social class at the time of the child's birth was then obtained as follows: I, professional and assumed the most advantaged, II, managerial, IIIN, skilled non-manual, IIIM, skilled manual, IV, semiskilled and V, unskilled and assumed to be the least advantaged. The classes were subsequently collapsed into three based on close correlations between the groups, for simplicity and also for ease of comparisons with other studies as follows: class I/II, class IIIN/M and class IV/V. Those for whom paternal occupation was not available from the birth certificates or for whom there was no suitable occupational code (including the 'unemployed' and 'students') were placed into a separate group to allow further comparisons to be made.

Age at diagnosis was categorised as follows: $\leqslant 1$ year, $2-4$ years, 5-9 years and 10-14 years. These categories represent the paediatric malignancies groupings used in most studies and in clinical risk stratifications, enabling comparisons to be made with other studies. Year of diagnosis was categorised as follows: 1968-1977, 1978-1987, 1988-1997, 1998-2010, with a further analysis for acute lymphoblastic leukaemia (ALL) by trial start and finish dates. Trial dates used for ALL cases aged 1-14 years followed the trial dates that were open in Great Britain during the study period (Stiller et al, 2012). The trial years followed were: January 1968-December 1975 (trials before UKALL V), January 1976- August 1980 (UKALL V, UKALL VI and UKALL VII were grouped together due to small numbers and overlapping dates), September 1980-December 1984 UKALL VIII, January 1985-September 1990 UKALL X, October 1990-February 1997 UKALL XI, March 1997-November 2002 ALL 97, October 2003December 2010 ALL 2003. White blood cell count was categorised based on prognostic implications (Bonilla et al, 2010) as follows: low $\left(\leqslant 50000\right.$ cells per $\left.\mathrm{mm}^{3}\right)$ and high $\left(>50000\right.$ cells per $\left.\mathrm{mm}^{3}\right)$.

Statistical methods. All variables were treated as categorical variables, as defined above. Survival time was the duration from diagnosis to death from any cause or the last day of availability of survival information in the NRYPMDR (the earliest of known date of loss to follow-up or 31 December 2010). This resulted in a binary survival variable with two levels; death or censored. KaplanMeier methods were used to calculate 1-, 5- and 10-year survival rates by categorical variables, cases diagnosed in the later years of the study period, 5- and 10-year survival was treated as censored. Cox regression analysis was used to multivariable model the associations between SES and survival, while adjusting for potential confounding and effect modification. Hazard ratios (HRs) and corresponding 95\% confidence intervals are reported. Interactions were formally tested within the Cox regression modelling framework. Other associations between categorical variables were assessed using the chi-squared test. Confounding was investigated by assessing changes in the SES coefficients on the introduction of other variables to the Cox regression models. The statistical software package STATA, version 11.0 (StataCorp, College Station, TX, USA), was used for all statistical analysis.

\section{RESULTS}

Of the 1007 children diagnosed with leukaemia from 1968 to 2010 in the NRYPMDR dataset and included in this analysis, 565 (56\%) were boys and 442 (44\%) girls. Descriptive statistics for the included patients are given in Table 1. Age at diagnosis ranged from 0 to 14 years with a median of 4 years and an inter-quartile range of 2 to 8 years. The modal social class category was the middle IIIn/IIIm category. Paternal social class was unknown (i.e. uncodable or missing birth certificates) for 181 (18\% cases). Over $80 \%$ of included cases had a diagnosis of ALL. The white blood cell counts at diagnosis ranged from 900 cells (per $\mathrm{mm}^{3}$ of blood) to $\sim 1.4$ billion cells per $\mathrm{mm}^{3}$ with a median of 8.1 million cells and an inter-quartile range of 2.7 million cells to 33.7 million cells per $\mathrm{mm}^{3}$. Ninety percent of ALL patients and $83 \%$ of acute myeloid leukaemia (AML) patients had white cell counts greater than 50000 cells per $\mathrm{mm}^{3}$ at diagnosis. There was a significant correlation between white cell count at diagnosis and calendar year (correlation coefficient $=0.52, P<0.0001$ ). For children with available data for WBC count at diagnosis, $100 \%$ of those diagnosed during 1968-1977 and 1978-1987 had counts greater than 50000 cells per $\mathrm{mm}^{3}$, while $98 \%$ of children diagnosed during 1988-1997 and 42\% of those diagnosed during 1998-2010 had 


\begin{tabular}{|c|c|}
\hline Variable & $\mathbf{N}$ (\% of total) \\
\hline \multicolumn{2}{|l|}{ Sex } \\
\hline $\begin{array}{l}\text { Female } \\
\text { Male }\end{array}$ & $\begin{array}{l}442(44) \\
565(56)\end{array}$ \\
\hline \multicolumn{2}{|l|}{ Age at diagnosis (years) } \\
\hline $\begin{array}{l}0-1 \\
2-4 \\
5-9 \\
10-14\end{array}$ & $\begin{array}{l}139(14) \\
386(38) \\
283(28) \\
199(20)\end{array}$ \\
\hline \multicolumn{2}{|l|}{ Calendar period of diagnosis } \\
\hline $\begin{array}{l}1968-1977 \\
1978-1987 \\
1988-1997 \\
1998-2010\end{array}$ & $\begin{array}{l}262(26) \\
231(23) \\
237(24) \\
277(27)\end{array}$ \\
\hline \multicolumn{2}{|l|}{ Paternal social class } \\
\hline $\begin{array}{l}\text { I/II } \\
\text { IIIN/M } \\
\text { IV/N } \\
\text { Unknown }\end{array}$ & $\begin{array}{l}170(17) \\
467(46) \\
189(19) \\
181(18)\end{array}$ \\
\hline \multicolumn{2}{|l|}{ White blood cell count per $\mathrm{mm}^{3}$} \\
\hline $\begin{array}{l}<50000 \text { cells } \\
>50000 \text { cells } \\
\text { Missing data }\end{array}$ & $\begin{array}{c}86(8) \\
701(70) \\
220(22)\end{array}$ \\
\hline \multicolumn{2}{|l|}{ Diagnostic type } \\
\hline $\begin{array}{l}\text { Acute lymphoblastic leukaemia } \\
\text { Acute non-lymphocytic leukaemia } \\
\text { Chronic myeloid leukemia } \\
\text { Others specified } \\
\text { Unspecified }\end{array}$ & $\begin{array}{c}823(82) \\
144(14) \\
17(2) \\
11(1) \\
12(1)\end{array}$ \\
\hline Total & 1007 \\
\hline
\end{tabular}

counts greater than 50000 cells per $\mathrm{mm}^{3}$. There was no association between white blood cell count and SES $(P=0.75)$. Over the 42 -year study period and irrespective of the year of diagnosis, a total of $436(43.3 \%)$ children died, while $7(0.70 \%)$ were lost to follow-up before 31 December 2010. The remainder were still alive as at 31 December 2010.

The crude survival estimates and unadjusted HRs are shown in Tables 2 and 3 for ALL and AML, respectively. Survival at each time point was greatest in the most advantaged social class group, with much wider disparities seen for 5 and 10 years survival compared with 1 year. There was little difference between the two more disadvantaged groups at any time point. Survival also increased over time, was higher in the middle two age groups than the youngest and oldest patients, was higher in those with a low white blood cell count, varied between leukaemia subtypes and improved significantly for ALL cases aged 1-14 years and treated following the more recent treatment regimens. Females had a slightly higher survival than males. A sensitivity analysis, removing all missing occupational and white blood cell count data to leave 689 cases, showed that missing data for these variables did not affect the HRs or $P$-values.

The association between paternal social class at birth and survival from leukaemia remained highly significant after adjustment within the Cox regression models for other factors (Table 4). Similar results were seen when restricting cases to acute lymphoblastic leukaemia (Table 4). For acute non-lymphocytic leukaemia, there was not a significant association between paternal social class and survival. There were no significant interactions between paternal social class and any of the other variables included in the analysis, including year of diagnosis $(P>0.05)$. Table 5 shows the results of calendar period specific Cox regression models for ALL, with the smallest variation in survival between SES groups in the most recent calendar period. The assumption of proportional hazards was evaluated and met for all models.

\section{DISCUSSION}

This study has several relevant findings with respect to socioeconomic status and childhood leukaemia survival. First, the study is consistent in showing the socioeconomic disparity in paediatric leukaemia survival, using a large and long-term dataset with children from social class I/II having a clear survival advantage over children in classes IIIN/M and IV/V, respectively. Even after adjustments for potential confounders, the disparity between social class groups persisted, such that children in class IIIN/M had a $66 \%$ higher risk of death relative to those in class I/II, while children in class IV/V had a $96 \%$ higher mortality risk.

The NRYPMDR gives a relatively large sample size for such studies and has a high level of ascertainment and almost complete follow-up of cases (Cotterill et al, 2000). Furthermore, the integration of clinical prognostic factors such as WBC in the multivariable analysis enhances the validity of the findings, while confounding by ethnicity is unlikely due to the ethnically homogenous population of the study area, which has fewer than $2 \%$ ethnic minorities. The use of paternal occupation as an indicator of SES is another strength of the study, as this measure is not prone to the ecological fallacy. Paternal occupation was available at birth, but not at later time points such as at the time of diagnosis. However, while parents may change jobs, occupational social class is not as likely to change between birth and a diagnosis in childhood, even up to age 14 years, particularly when using broad social classes, so missing information on later socioeconomic status is unlikely to impact on our findings. However, in a minority of cases it may be that the father recorded on the birth certificate no longer has a role in the child's life (for example, due to death or divorce). It is also possible that having a child diagnosed with leukaemia may result in a change of occupation for at least one parent, which could result in a change in SES group, although a reduction in hours in the same job would not cause this. Data on such issues were not available to this study, but again are unlikely to impact on our findings due to the small number of patients that this would involve. Focusing only on an individual measure of SES has the tendency to ignore the broader issues of neighbourhood and ecological SES contextual effects on leukaemia survival. However, given that a similar study (Basta et al, 2011) from the NRYPMDR that used areal measures of SES did not find significant associations, it is likely that the 'individual fallacy' is less of an issue than the 'ecological fallacy'. Some groups of fathers were excluded from the main SES analysis (such as the unemployed, single mothers, unspecified students), so greater disparities in some groups may have been missed. Furthermore, the unavailability of certain information on the fathers' occupation such as the level of autonomy and working conditions, made it impossible to have used the more recent NS-SEC occupational classification of SES, which is more salient than the Registrar Generals classification.

Finally, the lack of availability of other possible individual measures of SES such as income and educational status of parents is another limitation as these would have provided more insight into the intricacies of SES and childhood leukaemia survival. 
Table 2. One-, five- and ten-year survival rates and unadjusted hazard ratios and $95 \%$ confidence intervals by demographic and clinical predictor factors for ALL cases only $(N=823)$

\begin{tabular}{|c|c|c|c|c|c|}
\hline Variable & $\begin{array}{c}\text { One-year survival } \\
(\%(95 \% \mathrm{Cl}))\end{array}$ & $\begin{array}{c}\text { Five-year } \\
\text { survival (\%) }\end{array}$ & $\begin{array}{c}\text { Ten-year } \\
\text { survival (\%) }\end{array}$ & $\begin{array}{c}\text { Hazard ratio } \\
(95 \% \mathrm{Cl})\end{array}$ & $\boldsymbol{P}$-value \\
\hline \multicolumn{6}{|l|}{ Sex } \\
\hline $\begin{array}{l}\text { Female } \\
\text { Male }\end{array}$ & $\begin{array}{l}86(82-90) \\
85(82-88)\end{array}$ & $\begin{array}{l}66(61-71) \\
62(58-66)\end{array}$ & $\begin{array}{l}63(57-68) \\
58(53-62)\end{array}$ & $\begin{array}{c}1.00 \\
1.20(0.96-1.49)\end{array}$ & 0.11 \\
\hline \multicolumn{6}{|l|}{ Age group (years) } \\
\hline $\begin{array}{l}0-1 \\
2-4 \\
5-9 \\
10-14\end{array}$ & $\begin{array}{l}73(63-81) \\
88(85-91) \\
90(85-93) \\
80(73-86)\end{array}$ & $\begin{array}{l}47(36-57) \\
69(64-74) \\
70(63-75) \\
53(45-61)\end{array}$ & $\begin{array}{l}44(34-54) \\
66(61-71) \\
63(57-70) \\
49(41-57)\end{array}$ & $\begin{array}{c}1.00 \\
0.47(0.34-0.65) \\
0.53(0.38-0.75) \\
0.82(90.57-1.17)\end{array}$ & $\begin{array}{c}<0.0001 \\
<0.0001 \\
0.27\end{array}$ \\
\hline \multicolumn{6}{|l|}{ Calendar period } \\
\hline $\begin{array}{l}1968-1977 \\
1978-1987 \\
1988-1997 \\
1997-2010\end{array}$ & $\begin{array}{l}67(60-73) \\
87(81-91) \\
94(89-96) \\
96(92-98)\end{array}$ & $\begin{array}{l}31(25-37) \\
62(54-68) \\
78(71-83) \\
88(82-92)\end{array}$ & $\begin{array}{l}27(21-33) \\
59(52-66) \\
71(64-76) \\
87(81-91)\end{array}$ & $\begin{array}{c}1.00 \\
0.38(0.29-0.50) \\
0.21(0.16-0.28) \\
0.11(0.07-0.17)\end{array}$ & $\begin{array}{l}<0.0001 \\
<0.0001 \\
<0.0001\end{array}$ \\
\hline \multicolumn{6}{|l|}{ Trial period for ALL aged $1-14$ years } \\
\hline $\begin{array}{l}\text { Before UKALL V (January 1968-December } \\
\text { 1975) } \\
\text { UKALL V, VI, VII (January 1976-August 1980) } \\
\text { UKALL VIII (September 1980-December } \\
\text { 1984) } \\
\text { UKALL X (January 1985-September 1990) } \\
\text { UKALL XI (October 1990-February 1997) } \\
\text { ALL } 97 \text { (March 1997-November 2002) } \\
\text { ALL } 2003 \text { (October 2003-December 2010) }\end{array}$ & $\begin{array}{l}56(48-63) \\
70(60-78) \\
86(76-92) \\
92(85-95) \\
95(90-98) \\
94(88-97) \\
98(93-100)\end{array}$ & $\begin{array}{l}19(14-25) \\
43(33-52) \\
63(52-72) \\
76(67-83) \\
80(72-85) \\
85(76-90) \\
92(85-96)\end{array}$ & $\begin{array}{l}16(11-22) \\
40(30-49) \\
60(48-69) \\
72(63-79) \\
72(64-79) \\
84(77-90) \\
-\end{array}$ & $\begin{array}{c}1.00 \\
0.49(0.37-0.66) \\
0.27(0.18-0.38) \\
0.17(0.12-0.25) \\
0.17(0.12-0.23) \\
0.09(0.06-0.14) \\
0.05(0.02-0.10)\end{array}$ & $\begin{array}{l}<0.0001 \\
<0.0001 \\
<0.0001 \\
<0.0001 \\
<0.0001 \\
<0.0001\end{array}$ \\
\hline \multicolumn{6}{|l|}{ Paternal social class } \\
\hline $\begin{array}{l}\text { I/II } \\
\text { IIIN/M } \\
\text { IV/N }\end{array}$ & $\begin{array}{l}90(84-94) \\
83(79-86) \\
86 \text { (79-91) }\end{array}$ & $\begin{array}{l}75 \text { (68-81) } \\
59(54-63) \\
62(53-69)\end{array}$ & $\begin{array}{l}72 \text { (64-78) } \\
56(51-61) \\
56(48-64)\end{array}$ & $\begin{array}{c}1.00 \\
1.73(1.25-2.40) \\
1.60(1.09-2.34)\end{array}$ & $\begin{array}{l}0.001 \\
0.02\end{array}$ \\
\hline \multicolumn{6}{|l|}{ White blood cell count } \\
\hline $\begin{array}{l}0-50000 \\
>50000\end{array}$ & $\begin{array}{l}97(89-99) \\
83(80-86)\end{array}$ & $\begin{array}{l}90(79-95) \\
59(55-63)\end{array}$ & $\begin{array}{l}85(73-92) \\
55(51-59)\end{array}$ & $\begin{array}{c}1.00 \\
4.26(2.19-8.28)\end{array}$ & $<0.0001$ \\
\hline
\end{tabular}

However, as the study is based in the United Kingdom, and within the National Health Service, which provides free treatment as part of a national health-care system, there are no issues with the ability to pay for consultation, diagnosis or treatment. Nevertheless, it would be useful for a further study to be able to look at components of socioeconomic status to aid understanding of the reasons behind such associations.

Our findings of higher survival among the more advantaged socioeconomic group are consistent with the findings of a recent large follow-up study, which examined the impact of social inequality on survival from childhood ALL on 1559 children (0-14 years) diagnosed in England, Scotland and Wales using data from the population-based UK Childhood Cancer Study (Lightfoot et al, 2012). Using both area-based deprivation scores and fathers occupational status, SES disparities in both measures were reported with a linear HR of 1.05 (1.01-1.09) per unit increase in area-level deprivation and a paternal social class linear HR of $1.16(0.99-$ 1.36) per rise in social class (Lightfoot et al, 2012). However, two other UK studies using areal data found no associations between socio-economic status and survival (Schillinger et al, 1999; Basta et al, 2011), while Walsh et al reported only weak trends in survival disparity from lymphoid leukaemia in relation to SES in Ireland (Walsh et al, 2011).

Findings on the relation between SES and childhood leukaemia survival in other countries are not necessarily reflective of the UK scenario due to the inherent differences in the health care and welfare systems. However, studies in Brazil (Ribeiro et al, 2007), China (Tang et al, 2008), Greece (Charalampopoulou et al, 2004) and South Korea (Son et al, 2011) have all reported findings consistent with those in this study from northern England. In contrast, a study from the Netherlands, assessing SES gradients in childhood leukaemia survival during the period of 1973-1979 reported that the educational level of parents had only minor impacts on childhood leukaemia survival (Coebergh et al, 1996). In the United States, which has a very different health-care system to the United Kingdom, poorer survival has been noted for ALL in children from a range of ethnic minorities, where ethnicity can be used as a proxy for SES (Goggins and Lo, 2012). No interaction was seen between SES and time period on survival, suggesting that SES inequalities in childhood leukaemia survival have not changed over the study period. However, there may have been changes that were too subtle given the statistical power of this study, as variability in 


\begin{tabular}{|c|c|c|c|c|c|}
\hline Variable & $\begin{array}{c}\text { One-year survival } \\
(\%(95 \% \mathrm{CI}))\end{array}$ & $\begin{array}{c}\text { Five-year survival } \\
(\%(95 \% \mathrm{CI}))\end{array}$ & $\begin{array}{c}\text { Ten-year } \\
\text { survival (\%) }\end{array}$ & $\begin{array}{c}\text { Hazard ratio } \\
(95 \% \mathrm{Cl})\end{array}$ & $\boldsymbol{P}$-value \\
\hline \multicolumn{6}{|l|}{ Sex } \\
\hline $\begin{array}{l}\text { Female } \\
\text { Male }\end{array}$ & $\begin{array}{l}55(43-66) \\
54(43-65)\end{array}$ & $\begin{array}{l}44(31-56) \\
41(30-52)\end{array}$ & $\begin{array}{l}44(31-56) \\
41(30-52)\end{array}$ & $\begin{array}{c}1.00 \\
1.10(0.71-1.70)\end{array}$ & 0.67 \\
\hline \multicolumn{6}{|c|}{ Age group (years) } \\
\hline $\begin{array}{l}0-1 \\
2-4 \\
5-9 \\
10-14\end{array}$ & $\begin{array}{l}57(39-72) \\
61(40-76) \\
58(41-72) \\
46(31-60)\end{array}$ & $\begin{array}{l}49(31-64) \\
50(30-66) \\
39(24-54) \\
35(21-50)\end{array}$ & $\begin{array}{l}49(31-64) \\
50(30-66) \\
39(24-54) \\
35(21-50)\end{array}$ & $\begin{array}{c}1.00 \\
0.94(0.47-1.88) \\
1.20(0.65-2.22) \\
1.31(0.72-2.38)\end{array}$ & $\begin{array}{l}0.86 \\
0.55 \\
0.39\end{array}$ \\
\hline \multicolumn{6}{|c|}{ Calendar period } \\
\hline $\begin{array}{l}1968-1977 \\
1978-1987 \\
1988-1997 \\
1997-2010\end{array}$ & $\begin{array}{l}20(10-33) \\
21(9-38) \\
91(69-98) \\
91(78-97)\end{array}$ & $\begin{array}{c}2(0-10) \\
14(5-30) \\
83(60-93) \\
80(64-89)\end{array}$ & $\begin{array}{c}2(0-10) \\
14(5-30) \\
83(60-93) \\
80(64-89)\end{array}$ & $\begin{array}{c}1.00 \\
0.65(0.40-1.08) \\
0.07(0.03-0.19) \\
0.07(0.03-0.15)\end{array}$ & $\begin{aligned} & 0.098 \\
< & 0.0001 \\
< & 0.0001\end{aligned}$ \\
\hline \multicolumn{6}{|c|}{ Paternal social class } \\
\hline $\begin{array}{l}\mathrm{I} / \mathrm{II} \\
\mathrm{IIIN} / \mathrm{M} \\
\mathrm{IV} / \mathrm{V}\end{array}$ & $\begin{array}{l}67(34-86) \\
56(41-68) \\
42(25-58)\end{array}$ & $\begin{array}{l}58(27-80) \\
41(28-55) \\
32(17-49)\end{array}$ & $\begin{array}{l}58(27-80) \\
41(28-55) \\
32(17-49)\end{array}$ & $\begin{array}{c}1.00 \\
1.47(0.57-3.80) \\
2.05(0.77-5.44)\end{array}$ & $\begin{array}{l}0.26 \\
0.43 \\
0.15\end{array}$ \\
\hline \multicolumn{6}{|c|}{ White blood cell count } \\
\hline $\begin{array}{l}0-50000 \\
>50000\end{array}$ & $\begin{array}{c}\text { No observation } \\
60(46-71)\end{array}$ & $\begin{array}{l}92(57-99) \\
48(36-60)\end{array}$ & $\begin{array}{l}92(57-99) \\
48(36-60)\end{array}$ & $\begin{array}{c}1.00 \\
9.44(1.29-69.11)\end{array}$ & 0.03 \\
\hline
\end{tabular}

Table 4. Cox regression analysis of paternal social class and survival from childhood leukaemia, adjusted for sex, age group, calendar time period and white blood cell count

\begin{tabular}{|l|c|l|}
\hline Social class & Hazard ratio (95\% Cl) & $\boldsymbol{P}$-value \\
\hline All leukaemias & & $<0.0001$ \\
\hline I/II & 1.00 & \\
IIIN/M & $1.66(1.20-2.29)$ & \\
IV/N & $1.96(1.35-2.86)$ & \\
\hline Acute lymphoblastic leukaemia & & $<0.0001$ \\
\hline I/II & 1.00 & \\
IIIN/M & $1.68(1.20-2.36)$ & \\
IV/N & $1.86(1.24-2.77)$ & \\
\hline \multicolumn{2}{|l}{} \\
Abbreviation: $\mathrm{Cl}=$ confidence interval.
\end{tabular}

survival between the SES groups was lowest in most recent calendar period.

Disparities in cancer survival are not the direct effect of social class, but are rather due to intervening factors between SES and survival. Possible aetiologies for such disparities have been less thoroughly and less systematically studied largely due to the complexity of the concept of social class. A review by Woods et al (2006) identified possible mechanisms linking SES and cancer survival broadly classified into three groups-tumour characteristics (stage at diagnosis and tumour biological features), patient characteristics (comorbidity, nutrition, psychosocial factors) and health-care factors (variation in treatment and medical expertise) (Woods et al, 2006). Stage at diagnosis is the most important factor with an SES gradient for solid tumours, especially for malignancies such as breast cancer and colorectal cancer, and often represents delay in health seeking or health provision by health providers (Coleman et al, 2003; Woods et al, 2006). For childhood leukaemia, white blood cell count is often used as a proxy for stage. As such, it is plausible that variations in white blood cell count may serve as the link between SES and leukaemia survival. However, there was no association between white blood cell count and SES and there was also no evidence of confounding associated with it as the SES HRs did not change when adjusted for white blood cell count. Information on other prognostic factors, such as cytogenetics and molecular biology subtypes was not available to this study and may represent factors that could explain the observed associations between SES and survival in a mediating role, or could also represent residual confounding.

Much wider disparities in survival were seen for 5- and 10-year survival compared with 1 year. This suggests that adherence to treatment may be more important than delays in diagnosis. Non-adherence to treatment is highest in adolescents in general (DiMatteo, 2004). A recent study of leukaemia patients from France found that while intentional non-adherence was rare, non-intentional non-adherence was common (Mancini et al, 2012). While this increased with age, it was also present in the paediatric patients. Disadvantaged socioeconomic status was also associated with increased non-adherence, consistent with a previous study of acute lymphoblastic leukaemia patients in Brazil (de Oliveira et al, 2004).

The existence of significant socioeconomic disparities in survival from childhood leukaemia in the twenty-first century is an important public health problem and suggests that policy implications need to be fully addressed, including adherence to treatment and quality of care. Equal access to high-quality treatment might be presumed in a country like the United 


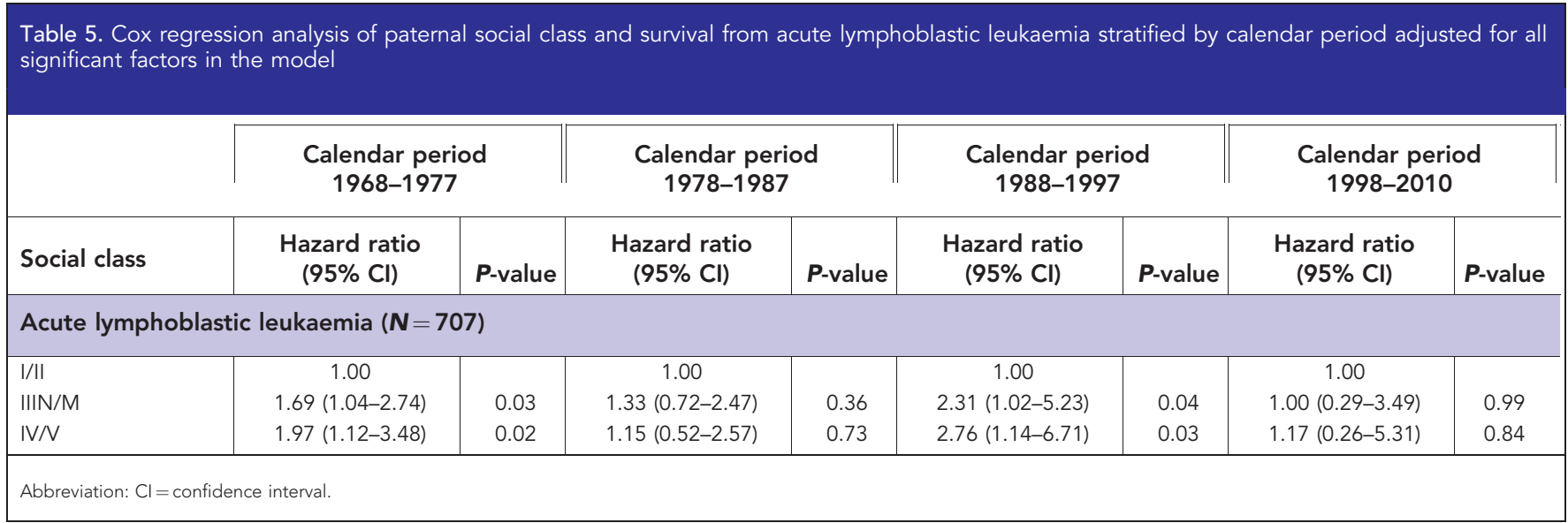

Kingdom, but it may also be the case that SES-related issues in seeking and obtaining care are also involved. Further research is required to clarify the aetiology of these social class differences and to identify factors that could be used for developing strategies to diminish such inequalities. Adequate systems should also be put in place to monitor future socioeconomic childhood leukaemia survival trends.

\section{ACKNOWLEDGEMENTS}

This work formed the project for KN's MSc in Public Health and Health Services Research at Newcastle University, funded by the Commonwealth Scholarship Commission. We thank the North of England Children's Cancer Research Fund for their continued support of the Cancer Registry epidemiological research and for partly funding NB, and Katharine Kirton for providing her expertise in occupational and social class coding.

\section{REFERENCES}

Adler NE, Newman K (2002) Socioeconomic disparities in health: pathways and policies. Health Aff (Millwood) 21: 60-76.

Basta NO, James PW, Gomez-Pozo B, Craft AW, McNally RJQ (2011) Survival from childhood cancer in northern England, 1968-2005 Br J Cancer 105: 1402-1408.

Bonilla M, Gupta S, Vasquez R, Fuentes SL, de Reyes G, Ribeiro R, Sung L (2010) Predictors of outcome and methodological issues in children with acute lymphoblastic leukaemia in El Salvador. Eur J Cancer 46: 3280-3286.

Cancer Research UK (2012) Childhood cancer incidence statisticsAvailable at http://info.cancerresearchuk.org/cancerstats/childhoodcancer/incidence/ \#leuk (Accessed date: 17 December 2012).

Chang CM, Su YC, Lai NS, Huang KY, Chien SH, Chang YH, Lian WC, Hsu TW, Lee CC (2012) The combined effect of individual and neighborhood socioeconomic status on cancer survival rates. PLoS One 7: e44325.

Charalampopoulou A, Petridou E, Spyridopoulos T, Dessypris N, Oikonomou A, Athanasiadou-Piperopoulou F, Baka M, Kalmanti M, Polychronopoulou S, Trichopoulos D (2004) An integrated evaluation of socioeconomic and clinical factors in the survival from childhood acute lymphoblastic leukaemia: a study in Greece. Eur J Cancer Prev 13: 397-401.

Coebergh JWW, van der Does-van denBerg A, Hop WC, van Weerden F, Rammeloo JA, van Steensel HA, van Wering ER, Kamps WA (1996) Small influence of parental educational level on the survival of children with leukaemia in The Netherlands between 1973 and 1979. Eur J Cancer 32A: 286-289.

Coleman MP, Rachet B, Woods LM, Mitry E, Riga M, Cooper N, Quinn MJ, Brenner H, Esteve J (2004) Trends and socioeconomic inequalities in cancer survival in England and Wales up to 2001 Br J Cancer 90: 1367-1373.
Coleman MP, Gatta G, Verdecchia A, Esteve J, Sant M, Storm H, Allemani C, Ciccolallo L, Santaquilani M, Berrino F. EUROCARE Working Group (2003) EUROCARE-3 summary: cancer survival in Europe at the end of the 20th century. Ann Oncol 14: V128-V149.

Cotterill SJ, Parker L, Malcolm AJ, Reid M, More L, Craft AW (2000) Incidence and survival for cancer in children and young adults in the North of England, 1968-1995: a report from the northern region young persons' malignant disease registry. Br J Cancer 83: 397-403.

de Oliveira BM, Viana MB, Zani CL, Romanha AJ (2004) Clinical and laboratory evaluation of compliance in acute lymphoblastic leukaemia. Arch Dis Child 89: 785-788.

DiMatteo MR (2004) Variations in patients' adherence to medical recommendations: a quantitative review of 50 years of research. Med Care 42: 200-209.

Goggins WB, Lo FF (2012) Racial and ethnic disparities in survival of US children with acute lymphoblastic leukemia: evidence from the SEER database 1988-2008. Cancer Causes Control 23: 737-743.

Kent EE, Sender LS, Largent JA, Anton-Culver H (2009) Leukemia survival in children, adolescents, and young adults: influence of socioeconomic status and other demographic factors. Cancer Causes Control 20: 1409-1420.

Lightfoot TJ, Johnston WT, Simpson J, Smith AG, Ansell P, Crouch S, Roman E, Kinsey SE (2012) Survival from childhood acute lymphoblastic leukaemia: The impact of social inequality in the United Kingdom Eur J Cancer 48: 263-269.

Mancini J, Simeoni MC, Parola N, Clement A, Vey N, Sirvent N, Michel G, Auquier P (2012) Adherence to leukemia maintenance therapy: A comparative study among children, adolescents, and adults. Pediatr Hematol Oncol 29: 428-439.

Marmot M, Friel S, Bell R, Houweling TA, Taylor S (2008) Closing the gap in a generation: health equity through action on the social determinants of health. Lancet 372: 1661-1669.

McWhirter WR, Smith H, McWhirter KM (1983) Social class as a prognostic variable in acute lymphoblastic leukaemia. Med J Aust 2: 314-321.

Pui CH, Carroll WL, Meshinchi S, Arceci RJ (2011) Biology, risk stratification, and therapy of pediatric acute leukemias: an update. J Clin Oncol 29: 551-565.

Quaglia A, Lillini R, Mamo C, Ivaldi E, Vercelli M (2013) Socio-economic inequalities: A review of methodological issues and the relationships with cancer survival. Crit Rev Oncol Hematol 85: 266-277.

Rachet B, Ellis L, Maringe C, Chu T, Nur U, Quaresma M, Shah A, Walters S, Woods L, Forman D, Coleman MP (2010) Socioeconomic inequalities in cancer survival in England after the NHS cancer plan. Br J Cancer 103: $446-453$.

Ribeiro KB, Lopes LF, de Camargo B (2007) Trends in childhood leukemia mortality in Brazil and correlation with social inequalities. Cancer 110: 1823-1831.

Saldana-Ruiz N, Clouston SA, Rubin MS, Colen CG, Link BG (2013) Fundamental causes of colorectal cancer mortality in the United States: understanding the importance of socioeconomic status in creating inequality in mortality. Am J Public Health 103: 99-104.

Schillinger JA, Grosclaude PC, Honjo S, Quinn MJ, Sloggett A, Coleman MP (1999) Survival after acute lymphocytic leukaemia: effects of socioeconomic status and geographic region. Arch Dis Child 80: 311-317.

Simard EP, Fedewa S, Ma J, Siegel R, Jemal A (2012) Widening socioeconomic disparities in cervical cancer mortality among women in 26 states, 1993-2007. Cancer 118: 5110-5116. 
Smith OP, Hann I (2004) Pathology of leukaemia. In Paediatric Oncology, Pinkerton CR, Ploughman PN, Pieters R (eds) 3rd edn, pp 84-89. Arnold: London.

Son M, Kim J, Oh J, Kawachi I (2011) Inequalities in childhood cancer mortality according to parental socioeconomic position: A birth cohort study in South Korea. Sco Sci Med 72: 108-115.

Stiller CA, Kroll ME, Pritchard-Jones K (2012) Population survival from childhood cancer in Britain during 1978-2005 by eras of entry to clinical trials. Annal Oncol 23: 2464-2469.

Tang Y, Xu X, Song H, Yang S, Shi S, Wei J (2008) Long-term outcome of childhood acute lymphoblastic leukemia treated in China. Pediatr Blood Cancer 51: 380-386.
Walsh PM, Byrne J, Capra M, Comber H (2011) Childhood cancer survival in Ireland: Temporal, regional and deprivation-related patterns. Eur J Cancer 47: $1852-1862$.

Woods LM, Rachet B, Coleman MP (2006) Origins of socio-economic inequalities in cancer survival: a review. Ann Oncol 17: 5-19.

This work is published under the standard license to publish agreement. After 12 months the work will become freely available and the license terms will switch to a Creative Commons AttributionNonCommercial-Share Alike 3.0 Unported License. 